\title{
Critical Literary Cartography: Text, Maps and a Coleridge Notebook
}

\section{David Cooper}

\section{Beyond Metaphorical Mappings: Towards Critical Literary Cartography}

In their edited collection, Envisioning Landscapes, Making Worlds, Stephen Daniels et al bring together twenty-nine transdisciplinary essays which exemplify 'the recent resurgence of intellectual interplay between geography and the humanities' (Richardson 2011: xix). Collectively, these papers showcase the pluralistic ways in which contemporary geographical theory has enriched the spatial thinking of scholars working across the arts and humanities. At the same time, the contributions highlight 'the reciprocal process' by which arts and humanities research has 'helped initiate changes in geography itself, stretching its traditional boundaries and applications in new directions' (Richardson 2011: xix). To facilitate identification of the key tropes within the dynamic interdisciplinary field of 'geohumanities', the editors codify four overlapping and intersecting 'modes of knowing the world' which 'frame specific geographical practices': reflecting, representing, performing and mapping (Daniels et al 2011: xxx). ${ }^{1}$ In introducing the last of these four cardinal themes, Daniels et al indicate how mapping 'as a term of cultural description in the arts and humanities has moved beyond the practice of cartography to a broader, metaphorical sense of interpreting and creating images and texts and of making sense of a fast modernizing or post-modernizing of this world' (Daniels et al 2011: xxx). The interdisciplinary currency of the term 'mapping', then, is at least partly attributable to the helpful malleability of its metaphorical applications. 
As well as embracing this conceptual potentiality, however, it is important to remain sensitive to what might be lost through this process of metaphorization. The epistemological problems associated with this transdisciplinary predilection for mapping metaphors can be traced in the field of literary studies. Writing in the Times Literary Supplement in 1998, John Kerrigan charted the ways in which the so-called 'spatial turn' across the humanities and social sciences was shaping and enriching contemporary critical practice in the final years of the twentieth-century. According to Kerrigan, a widespread willingness to engage with a diverse range of theories of space and place - from the phenomenology of Martin Heidegger to the post-Lefebvrean socio-spatial thinking of Edward Soja - was highlighting the rich imbrications and synergies between geographical thinking, creative writing and the interpretative processes of the literary critic. As part of this spatialization of literary studies, the influence of the postmodern thinking of Fredric Jameson led to "much discussion of cognitive mapping' (Kerrigan 1998: 3). By extension, the verb, 'to map', became increasingly synonymous with the concatenated practices of reading, textual analysis and critical taxonomy rather than the surveillance and representation of the geographical landscape. This process of de-cartographization was further acknowledged by Melba Cuddy-Keane in an essay entitled 'Imaging/Imagining Globalization: Maps and Models'. In exploring the proliferation of mapping metaphors in recent humanities and social sciences research, Cuddy-Keane stressed that spatial usage often remained inextricably interlinked with 'our increasingly globalized consciousness of the world' (Cuddy-Keane 2002). Yet, at the same time, she indicated how, through the utilization of mapping as a strategic conceit, critics were, in fact, widening the disjuncture between literary and geographical definitions and understandings of maps and mapping practices. 
It is salient, then, that the historical geographer, Keith D. Lilley, has recently struck a cautionary note regarding the ways in which the term, 'mapping', has become increasingly deracinated from its cartographic roots: 'At a time when figurative and metaphorical "mappings" are becoming particularly prominent $[\ldots]$ it is perhaps worth underlining the benefits of still thinking about maps and "map-making" in a more conventional and literal sense' (Lilley 2011: 30-1). For Lilley, therefore, the ongoing spatialization of much arts and humanities research is the cause for both intellectual celebration and moderate concern. That is to say, genuinely interdisciplinary geohumanities research needs to be predicated upon a self-reflexive engagement with geographical thinking and practices rather than an uncritically imprecise reliance on spatial vocabularies and discourses. More particularly, such research needs to be informed by the work of J. B. Harley, Denis Wood and other key critical cartographers: theoretical thinking which is 'avowedly political in its analysis of mapping praxis' and which seeks 'to deconstruct the work of spatial representations in the world and the science that produces them' (Kitchin et al 2009: 10).

Lilley's observations chime with ideas articulated by Andrew Thacker in his formulation of 'critical literary geography': a mode of literary criticism which is founded, at least in part, upon cartographic principles and practices. For Thacker, 'difficulties' arise when literary critics use 'geographical tropes without closer consideration of the implications of such terms' (Thacker 2005/6: 62); and he proposes that literary scholars ought to eschew mapping metaphors in favour of a critical engagement with 'actual maps $[\ldots]$ in order to accentuate a more materialist understanding of the spatiality of texts' (Thacker 2005/6: 64). Literary cartography - a key sub-strand of Thacker's holistic model of 'critical literary geography' - can be divided into two additional categories: authorial and reader-generated mappings. ${ }^{2}$ 
Authorial mappings are those cartographic representations of geographical space which are embedded within literary texts. According to Thacker, geocritics might read such literary cartographies 'with an understanding of specific historical geographies' and an awareness of 'debates within cultural geography surrounding space and place' (Thacker 2005/6: 65). ${ }^{3}$ Moreover, geocritics might remain alert to the precise emplacement of such literary maps within the material context of the published text since 'equal attention must be paid to the textuality, visual and verbal, of the spaces represented, and to the spatialities of the text itself' (Thacker 2005/6: 65). Alongside this, literary critics might expand their interpretative practices by producing readergenerated mappings: cartographical representations of space based upon geocritical analyses of literary texts. Clearly, this shift towards map-making leads to the proliferation of practical and theoretical questions. Are technical skills necessarily required for the production of such critical maps? Can multiple literary texts be mapped onto a single cartographical space? How might the geocritical map-maker differentiate between the textual representation of actual and fictional places? The endeavour to resolve such issues, however, clearly carries the potential to open up new ways of thinking about the praxis of literary cartography: thinking which, in turn, intersects with recent post-representational explorations of the processual nature of maps and mapping practices (Kitchin and Dodge 2007).

This chapter responds to Thacker's proposed re-cartographization of literary mapping practices through a spatial reading of the authorial maps to be found in a single text: a discrete notebook kept by the Romantic poet, Samuel Taylor Coleridge (1772-1834), during a celebrated nine-day walking tour of the western half of the Lake District in August 1802. As a result, the chapter self-consciously reacts to Thacker's suggestion that the cardinal characteristics of critical literary geography 
might involve the analysis of 'the occurrence of maps and mapping in specific texts' and the consideration of 'how cartography functions as an instance of visual culture in such texts' (Thacker 2005/6: 64). The cartographical representations of the Cumbrian landscape to be found within Coleridge's pocketbook, then, can be read from a series of intersecting critical perspectives: they can be contextualized through reference to 'specific historical geographies'; they can be analyzed through the conceptual frameworks provided by recent thinking in the field of critical cartography; and they can be examined in terms of the ways in which their graphic materiality both contains and shapes spatial meaning. In addition, the chapter highlights some ways in which cartographical representations of space have been, and can be, produced through a geocritical engagement with Coleridge's text; and, more specifically, it gestures towards the ways in which innovative digital mapping technologies and techniques might advance the analytical practices of the critical literary cartographer. Ultimately, therefore, the chapter is informed by two imbricated aims: to develop theoretical thinking about the particularities of Coleridge's maps and mapping practices; and to use Coleridge's notebook to open up ways of conceptualizing critical literary cartography.

\section{Writing as Process: Introducing Coleridge's Notebooks}

Between 1794 and 1834, Samuel Taylor Coleridge (1772-1834) habitually wrote in notebooks. As Seamus Perry points out, there are seventy-two individual volumes 'of very different sizes and put to diverse sorts of purpose': 'Some notebooks are sturdy and well-bound in leather; others small pocket-books which came with a pencil. He kept some of the notebooks as desk books, copying into them, in ink, entries he had first scribbled, in pencil, in pocket-books balanced on his knee as he travelled in a 
coach or leant against a rock' (Perry 2002: xi). Kathleen Coburn, the editor of Coleridge's Notebooks, has observed that a critical engagement with these textual spaces enables us 'to catch one of the great minds in human history in its wide range of introspection, observation, and analysis, looking at what interests him, and following his eye where his attention and imagination direct him' (Coburn 1974: 3). The notebooks, then, are difficult-to-define textual spaces in which Coleridge records his emergent thoughts and observations on a bewilderingly heterogeneous range of themes and topics. Significantly, Coleridge regularly picked up whichever book happened to be ready-to-hand. As well as referring to a diverse range of subjects, therefore, individual pocketbooks also confusingly contain entries which were inserted at different stages of the poet's life and imaginative development.

In the present chapter, I am exclusively interested in what Coleridge himself numbered notebook 2: a pocketbook, now held at the British Library, which the poet filled during his walking tour of August 1802. Notebook 2 is a text which can be read as a phenomenological articulation of the enmeshed processes of pedestrian practice and on-the-spot environmental observation. Saliently, it is also an example of literary fieldwork in which Coleridge showcases his interest in the roles played by cartography in both the acquisition of geographical experience and the development of the spatial imagination. The Lake District notebook, therefore, is a processual space in which Coleridge thinks geographically through both text and a range of maps and mapping practices.

\section{Map-Mindededness: Contextualizing Coleridge's Cartography}

As Denis Cosgrove puts it, Brian Harley opened 'the field of cartographic study far beyond a technical and internalist history of what had conventionally passed for a 
"map", at least in the West': a theoretically pluralistic project which 'influenced thought well beyond his [Harley's] own discipline of geography' (Cosgrove 1999: 3). For the geocritic, Harley's post-structuralist theorizing is especially helpful in facilitating further thinking about the symbolic textuality of 'actual' literary cartographies: 'Maps are text in the same senses that other nonverbal sign systems paintings, prints, theater, films, television, music - are texts. [ . . ] Maps are a graphic language to be decoded' (Harley 2001: 36). According to Harley, there is a need for the critical cartographer to deconstruct the 'false dichotomy between an externalist and an internalist approach to historical interpretation': a binary opposition which shapes the tendency to "regard context as "out there" and the maps we are studying as "inside" (Harley 2001: 38). It is a move which prompts Harley 'to distinguish between three aspects of context that intersect the reading of maps as texts': 'the context of the cartographer, the contexts of other maps, and the context of society' (Harley 2001: 38).

Before considering Coleridge as cartographer, then, it is illuminating to reflect upon the final two interwoven elements of Harley's tripartite model. First, Coleridge's authorial mappings can be placed within the social context provided by contemporaneous cultural attitudes towards mapping, map-reading and map-making. In her biography of the Ordnance Survey, Rachel Hewitt comprehensively details the complex and varied ways in which Britons became "'map-minded" over the eighteenth-century' (Hewitt 2010: 203). In the latter stages of the 1700s, maps and mapping practices were increasingly prevalent tropes within literary texts; and, as Hewitt points out, actual cartographies even figured in 'embroidery and board games' (Hewitt 2010: 203). Cartographical representations of the physical landscape, therefore, were brought indoors to feature within quotidian leisure practices; 
domesticated maps were variously read, made and played upon. Yet, in spite of the playful performativity which underpinned such everyday activities, the popularity of maps was simultaneously predicated upon what Hewitt refers to as 'the Enlightenment's celebration of cartography as the language of reason and political equality' (Hewitt 2010: 203). That is to say, maps were the material products of a teleological process founded upon the trigonometric surveillance of landscape. Moreover, the development of Enlightenment cartographic practices was inextricably entwined with military history as maps were used as both 'tactical military tools and as illustrative aids to describe the conflict [with France] to the reading public' (Hewitt 2010: 203). At the end of the eighteenth-century, then, maps were characterized by the paradoxes which continue to define cartographies in the twenty-first century: on the one hand, they were positivist products of rationalist discourses and practices; yet, simultaneously, they were imaginative and even fancifully decorative representational spaces.

Such paradoxes informed the ambivalent, and frequently contradictory, responses to cartography and cartographic practices voiced by the first-generation Romantic poets. As Hewitt delineates, both William Blake and William Wordsworth articulated - in different ways and with varying degrees of hostility - a protophenomenological aversion towards the principles of Euclidean geometry which underpinned Enlightenment map-making and which flattened the textural topography to a two-dimensional system of abstract signs. Yet, in spite of their shared suspicion of the work of official cartographers, both writers were also seduced by the imaginative powers of maps and mapping practices; and, as Hewitt puts it, they 'defended the importance of the imagination and emotions against Enlightenment reason' but, crucially, 're-appropriated maps as images of these faculties' (Hewitt 2010: 207). 
Coleridge's cartography can also be situated within the second of Harley's categories of contextualization: the representations of geographical space offered by other maps. More particularly, Coleridge's maps can be placed within the locospecific context set up by other literary maps of the Lake District which, in turn, opens up wider thinking about the cartographic intertextuality of this culturally overdetermined landscape in north-west England. From the middle of the eighteenthcentury, the singular topography of the Lakes was increasingly subjected to textual representation, often in the form of first-person accounts (in both poetry and prose) of moving through this precipitous landscape of fells and lakes, screes and becks. As Peter Bicknell points out, however, little 'reference was made in eighteenth-century [Lake District] tours to maps' (Bicknell 1990: 13). It is a surprising cartographical absence which is similarly detected by Julia S. Carlson who notes how the 'first edition of Thomas West's Guide to the Lakes (1778) - the first of the region's [Picturesque] guidebooks for tourists - contained neither map nor pictorial matter though it famously identified locations ['Stations'] for viewing scenic prospects' (Carlson 2010: 73). Although the third edition of West's popular Guide (1784) contained a map of the region, its scale ('one-quarter inch to the mile') failed to provide the visitor with sufficient topographical detail; and, as a result, touristic mapping practices were often, and necessarily, based upon the consultation of official county maps of Cumberland, Westmorland and north Lancashire (Carlson 2010: 73). As Carlson notes, however, these large county cartographies were not produced with the peripatetic tourist in mind and, as a result, could not be carried on location: a problem of portability which was identified by enterprizing map-makers who subsequently drew upon the detail to be located upon the county cartographies to produce new pocket maps which could be carried 'close to the body' and consulted 
'on the spot' (Carlson 2010: 74). As a result, Hewitt suggests that Coleridge's mapping practices were 'prophetic': his portable cartography 'demonstrated how invaluable maps were to travellers who did not want to be coupled to a guide, confined to a set route or chained to the road' (Hewitt 2010: 211).

\section{Map-Making: Coleridge as Cartographer}

There has been an understandable tendency for populist accounts to valorize Coleridge's solitary walking tour of August 1802 as a seminal moment in the histories of both the cultural geography of the Lake District and British mountaineering. At the beginning of his notebook, Coleridge, in characteristically fragmentary prose, underlines the self-determining nature of his own embodied movement across the Cumbrian terrain: 'mossy soft ground, every man his own path-maker - skip \& jump - where rushes grow, a man may go' (Coleridge 1957: 1207). ${ }^{4}$ Coleridge's excursion has been feted as a self-consciously anti-Picturesque spatial practice; a new type of tour which opened up fresh ways of seeing the Cumbrian landscape based upon spontaneously random pedestrian movements through the relatively wild, and culturally marginalized, topographies of the western Lakes. As Alan Hankinson puts it: 'It is hard, nowadays, to appreciate the sheer boldness of his undertaking. It was a journey without precedent' (Hankinson 1993: 18). Alongside this, Coleridge's famous account of his descent of Broad Stand - the notoriously precipitous set of rock steps which separates Scafell and Scafell Pike - has been frequently canonized as perhaps the foundational text in British climbing literature. It is a critical position which is exemplified by the topographical prose of Robert Macfarlane. In Mountains of the Mind, for instance, Macfarlane indicates that Coleridge's daredevilry 'began a century in which risk-taking in the mountains escalated' (Macfarlane 2003: 84). Whilst, in 
The Wild Places, Macfarlane celebrates the apparent haphazardness of Coleridge's corporeal processes: 'There was no obvious logic to the routes Coleridge chose to walk [...] he went, on the whole, where inclination and chance took him' (Macfarlane 2007: 208). Macfarlane's critical impulse, then, is to frame, and to romanticize, Coleridge as a proto-psychogeographic wanderer who unconceals spatial connections and patterns by instinctively following his feet.

This version of the 1802 walking tour results, at least in part, from a critical engagement with the self-mythologizing letters which Coleridge addressed to Sara Hutchinson: epistolary accounts, in the past-tense, in which the poet expansively and exuberantly dramatizes his own geographical experiences. ${ }^{5}$ At the same time, however, it is a critical analysis which, although not inaccurate, marginalizes the fact that Coleridge's pocketbook opens with a series of preparatory notes in which he sets out, and imaginatively anticipates, his proposed itinerary. The earliest entries contain notes in which Coleridge reminds himself to take advantage of local knowledge as he travels through the western vales: 'Enquire in Eskdale for Buck Crag, Doe Crag \& Earn Crag'; and 'Enquire at Muncaster for the Children's Ditty on New Year's Eve' (Coleridge 1957: 1205). ${ }^{6}$ The initial entries also contain geographical directions as Coleridge plans his proposed route across the fells: 'Go down Ulpha Park, down as far as Duddon Bridge, then cross, \& come out on Coniston/go up it, \& then mount $\mathrm{get}$ into the road to Kendal - return thro' Eskdale, go up Burnmoor Tarn, over into Wastwater or not as shall seem best' (Coleridge 1957: 1205). ${ }^{7}$ The textualized anticipation of geographical experience is then developed even further by Coleridge through the construction of a table used to calculate the distances that he plans to cover during each day of his walking tour. 
The projection of Coleridge as a spontaneously serendipitous path-maker is similarly problematized by the writer's insertion of a line-drawn map of the western part of the old county of Cumberland.

\section{[Insert figure 1]}

Figure 1: Coleridge's full-page map of the western Lake District

\section{(C) The British Library Board. Add.47497 f. 4}

At first, it appears to be an idiosyncratically personal map in which topographical accuracy is of secondary importance to establishing the relational topologies of the places Coleridge wishes to visit: the Cumberland coastline is preternaturally straight, for example; and the village of St Bees is erroneously shown to be further north than the touristic town of Keswick. In other words, it seems to be a singular map drawn exclusively for personal use; it is a geocentric cartography which is specifically constructed as part of the writer's prefiguring of his own egocentric movement through the Lakes. As Molly Lefebure, has pointed out, however, Coleridge's preparatory notes were based upon his reading of William Hutchinson's History of the County of Cumberland (1794); and, in preparing himself for the practice of mapmaking, Coleridge must have consulted the cartography inserted within this 'up-todate reference and guide' book (Lefebure 1974: 139) whilst he sat at his desk at the family home of Greta Hall, Keswick. It is an assumption which is supported by consultation of the Hutchinson map: a county cartography in which the landscape is rotated, in a clockwise direction, by approximately 45 degrees which means that north-west appears at the top of the printed page and St Bees is placed higher than Keswick upon the plane representational space. What is more, Coleridge reproduces 
the spelling and typographical sloping of place names to be found on the Hutchinson map (Coburn 1957b: 1206); and, in both maps, 'there is only a single Scafell' (Coburn 1957b: 1217). Coleridge's map-making practices, therefore, are based upon his experiential processes as a map-reader; and his seemingly singular map demonstrably replicates the geovisualization strategies embedded within an earlier cartographical representation of Cumberland.

The argument that Coleridge's cartography is copied from Hutchinson's History opens up thinking about the ways in which the writer's anticipation of embodied geographical experience was predicated upon his imaginative engagement with this earlier map. In redrawing the county map, Coleridge layers personal geographies on top of the 'official' cartographical representation of space: he draws a building at Keswick to symbolize his own home at Greta Hall; and a dotted line is sketched to signify his proposed route between Keswick and Buttermere. Yet, alongside such instances of personalization, Coleridge also unconsciously reinscribes the socio-spatial complexities silently encoded within the earlier geocentric cartography. In Harley's deconstructive analysis, 'all maps are rhetorical': 'As images of the world, maps are never neutral or value-free or ever completely scientific. Each map argues its own particular case' (Harley 2001: 37). Coleridge, in retracing the Hutchinson map - a map which, in turn, is based upon earlier regional cartographies by John Cary and Thomas Donald ${ }^{8}$ - incorporates a series of buildings in the west of the county, including the priory at St Bees, Egremont Castle and Calder Abbey. Even his own personalized mapping of Cumberland, therefore, offers a representational reiteration of the socio-spatial 'arguments', to apply Harley's formulation, embedded within a county cartography which is 'the paper world of an elite social class' (Harley 2001: 131). That is to say, the Hutchinson map envisions Cumberland as a network of 
ecclesiastical buildings and seats of aristocratic power as well as a material landscape of lakes, fells and forests: a social reading of cartographical space which is supported by the fact that the significant cost of publishing Hutchinson's History was funded by subscribers, many of whom were 'the nobility, clergy and gentleman of Cumberland' (Huddleston 1974: x). The Hutchinson map, then, corresponds with Harley's deconstructive analysis of map-making: 'Cartography deploys its vocabulary accordingly so that it embodies a systematic social inequality. The distinctions of class and power are engineered, reified, and legitimated in the map by means of cartographic signs' (Harley 2001: 158). ${ }^{9}$

As the reader moves through Coleridge's Lake District notebook, he or she encounters a diverse range of illustrations which the poet sketched as he walked through, over and across the Cumberland landscape. Many of these illustrations are geometric line drawings of the contoured Cumberland landscape: egocentric representations of the material topography based upon the poet's own embodied positionality within geographical space. These illustrations of actual geographic visions are supplemented by a series of drawings in which Coleridge imagines the landscape as perceived from a totalizing, aerial perspective: conventional plane-view cartographies which enable the walker to enhance his understanding of the topography through which he is passing. Towards the start of his walking tour, Coleridge proposes that the view from Egremont Castle is 'as impossible to describe to an other as a Dream' (Coleridge 1957: 1211). Throughout the notebook, then, Coleridge seeks to transcend the perceived limitations of a purely linguistic response to environmental experience by moving across the porous boundaries between landscape drawing and cartography, actual and imagined geographies. The complex range of Coleridge's geovisualization strategies can be located within a line-drawing of the 'Lake-part of 
Wastdale': a topographical feature which 'is impossible to conceive $[\ldots]$ without a drawing' (Coleridge 1957: 213).

\section{[Insert figure 2]}

\section{Figure 2: Coleridge's Map of the 'Lake-part of Wastdale'}

(C) The British Library Board. Add.47497 f. 11v

Here, Coleridge offers an image which disorientates the reader as the named topographical features - the high fells which encircle Wast Water - are completely transposed in the process of pictorial representation. It is a visual distortion of the Cumberland landscape which has been subjected to competing interpretations. For Hewitt, this 'topsy-turvy' inversion was 'not just a whim or folly'; but, rather, 'paralleled the looking-glass that Coleridge found in Wast Water itself' (Hewitt 2010: 211). Alternatively, Robin Jarvis parenthetically wonders whether the inversion of landscape might be attributable to the possibility that 'Coleridge was using that indispensable accessory of the picturesque tourist, the Claude Glass' on his walking tour of August 1802: a supposition which is supported by the fact that the drawing of Wasdale is not an isolated example as 'many of his [Coleridge's] verbal descriptions and sketch-maps [similarly] transpose left and right' (Jarvis 1997: 132). ${ }^{10}$ In both analyses, however, Coleridge's mapping practice is understood to have been based upon his own embodied experience of this particular place rather than a diagrammatic retracing of a pre-existing representation of space; a phenomenological mapping of texturalized place rather than an authoritative plane-view cartography. By extension, it is an illustration which corresponds with Cosgrove's assertion that vision is a complex word that incorporates both the oracular act of registering the external world, 
and a more abstract and imaginative sense of creating and projecting images' (Cosgrove 2008: 5).

\section{Coleridge's Cartography: Authorial and Editorial Mappings}

In her attempts to produce a 'useful' (Coburn 1957: xxi) edition of Coleridge's Notebooks, Coburn imposed a chronological structure predicated upon her indefatigable dating of each individual entry (7,000 in total: Worthen 2010:41) in each of the poet's pocketbooks. This textual process resulted in an edition which extracts sequential order out of the non-linear textual chaos of Coleridge's quotidian jottings. Yet, whilst acknowledging the magnitude of Coburn's editorial achievement, recent critics have also articulated an anxiety for what has been sacrificed through the systematic structuring of Coleridge's 'zigzagging accretions' (Cheshire 2009: 298). These are problems which were recognized by Coburn herself as she introduced a second numbering system to enable '[patient] readers interested in the composition of a single notebook [ . . ] to reconstruct it, approximately, from the tables at the end of the Notes volume' (Coburn 1957: xxi). The logical ambition to package Coleridge's notebooks into a linear form, however, inevitably led to the presentational marginalization of the richly confusing systems of palimpsestic intratextuality frequently embedded within a single material page; the chronology of composition was privileged over the textual spatiality of the poet's material pocketbooks.

The Lake District notebook is anomalous in that Coleridge untypically used this pocketbook as a self-contained, discrete space dedicated solely to the textual and visual documentation of his 1802 walking tour and 'the notebook was used in sequence from front to back' (Coburn 1957b: xxi): unusual textual practices which, in turn, raise questions about Coleridge's ultimate authorial intentions for the material 
collected in this particular book. As a result, this is a rare instance in which Coburn's chronological structure synchronizes with the sequential ordering of Coleridge's notebook entries. Yet, even here, the spatial architecture of the pocketbook is sacrificed as the fact that the reproduction of Coleridge's retracing of the Hutchinson map requires its own page means that it is placed after textual entries which it precedes in the original notebook. If possible, then, the original pocketbook should be read alongside Coburn's published edition: an argument which corresponds with Thacker's methodological proposition that the critical literary geographer ought to remain sensitive to the complex imbrications of the spatial materiality of texts and the textual representation of geographical spaces and places.

A geocritical engagement with Coleridge's original pocketbook facilitates further thinking about the writer's map-making practices. In the material space of the pocketbook, for example, the rigidly vertical line used to delineate the Cumberland coast (figure 1) is positioned immediately parallel to the outer edge of the page: a placement which then allows Coleridge to maximize the available textual space as his line-drawn map occupies the entire page. The physical dimensions of the textual space, therefore, can be seen to determine both the geometry and the scale of Coleridge's retracing of the Hutchinson map: a reminder that all maps - including literary cartographies - are necessarily delimited by the representational spaces in which they are drawn or printed. Coleridge himself draws attention to this triangulated relationship between geographical, textual and cartographical space when he indicates how Wastwater 'is inclosed in strait lines, exactly like the Sheet of paper, on which I am writing (Coleridge 1957: 1213).

By extension, then, Coleridge's Lake District notebook highlights the fact that is it possible - and perhaps even desirable - for the critical literary geographer to 
distinguish between at least two types of authorial mapping. First, there are those literary cartographies embedded within the published text. Even when such maps have been drawn by the writer of the text - as opposed to, say, a professional cartographer - such literary cartographies need to be understood as maps which have been subjected to the multifarious social filters of the editorial process; a process which, in turn, shapes the ways in which the relationship between text and map is presented to the reader. Second, there are literary cartographies embedded within a writer's own compositional spaces: maps which may prompt the geocritic to reflect upon both the writer's mapping practices and his or her own practices as a reader of the spatial text.

The geocritical potentiality opened up by this move towards textual scholarship is further underlined by the fact that Coburn fails to reproduce one of the cardinal examples of egocentric mapping to be found in Coleridge's original pocketbook.

\section{[Figure 3]}

Figure 3: Coleridge's Egocentric Mapping in South-West Cumberland

\section{(C) The British Library Board. Add.47497 f. 18v}

Here, the notebook page is clearly divided into two. The top half consists of fragmentary text in which Coleridge hesitantly endeavours to locate himself within the Cumberland landscape:

Bread Crag, - what I thought

Bowfell, is Ill Crags-

How Beck/

and Bread Crag \& Doe Crag-I went

down the How/- (Coleridge 1802: 18v) 
In the bottom half of the page, however, Coleridge turns to a pictorial representation of the topography in order to understand his own locatedness-in-space. Once again, the geometric configuration of this personalized mapping is shaped by the parameters of the textual space: Coleridge rotates the pocketbook to enable him to map out the contoured fell-line; and, as in the full-page map (figure 1), he uses the borders of the page to guide the movement of his own pen across the textual space. The symbolic significance of the asterix-type shape upon this straight line remains unspecified by Coleridge. Logic suggests, however, that it symbolizes the positionality of the writerin-landscape as he endeavours to name the peaks which he sees before him. In her Notes, Coburn acknowledges the existence of this 'rough diagrammatic attempt to suggest the relative positions of the sea' and a series of Cumberland fells (Coburn 1957b: 1219); but, in omitting this illustration from her edition of the Notebooks, Coburn marginalizes a map which offers an on-the-spot, embodied alternative to the geocentric, intertextual and social cartography to be found in Hutchinson's History.

\section{Reader-Generated Mappings: Digital Critical Practices}

The discussion of literary cartography has, so far, focused exclusively on Coleridge's own cartographical representations of space: the line-drawn maps to be found within the pages of his original pocketbook; and Coburn's reproduction of those mappings in her authoritative edition of the Notebooks. In the final section of this chapter, then, there is a need to pull back from detailed geocritical readings to suggest some ways in which reader-generated mappings of Coleridge's Lake District notebook might point, in broad terms, towards future developments in literary mapping practices. In establishing a methodological framework, Thacker turns to Franco Moretti's Atlas of 
the European Novel 1800-1900: a seminal work of 'literary geography' (Moretti 1998: 7). Moretti begins his experimental monograph by declaring two cardinal ambitions: first, he articulates his interest in eschewing purely metaphorical understandings of maps and mapping practices; and, second, he proposes to transcend an understanding of (creative and critical) literary maps as merely decorative paratexts (Moretti 1998: 3). ${ }^{11}$ By extension, Moretti sets up a critical methodology in which cartographical representations of space might be produced, by the literary critic, to 'dissect the text in an unusual way', thereby 'bringing to light [spatial] relations that would otherwise remain hidden' (Moretti 1998: 3). It is a cartographical approach which enables Moretti to interrogate both 'space in literature' and 'literature in space' (Moretti 1998: 3): the representation of geographical locations in nineteenth-century fictional texts; and the historical spaces and places in which those novels were consumed by readers. As several critics have observed, Moretti's model of 'literary geography' is not without its conceptual problems or limitations (Kerrigan 1998: 4; Thacker 2005/6: 601; Cooper and Gregory 2011: 92-3). Yet, in spite of such qualifications and reservations, Moretti's movement towards critical map-making clearly opens up conceptual space for the ongoing development of literary cartography.

The impulse to create reader-generated mappings of Coleridge's Lake District notebook has, in turn, led to the experimental use of digital mapping technologies. As Lilley points out, Geographic Information Systems (GIS) technology offers an increasingly accessible and user-friendly 'multi-media platform for all kinds of spatial information'; and although, to date, much digital humanities research has drawn upon GIS to create spatial visualizations of quantitative data, there has been a growing, and interdisciplinary, move to incorporate the technology within disparate strands of qualitative research (Lilley 2011: 26). The 'Mapping the Lakes' project, funded by the 
British Academy and based at Lancaster University, has contributed to this cultural shift towards qualitative GIS through the creation of digital maps of two key textual accounts of tours of the English Lake District: Thomas Gray's epistolary documentation of his proto-Picturesque journey of 1769; and, crucially, Coleridge's walking tour of $1802 .{ }^{12}$ For this project, the exploration of ways in which GIS might facilitate further thinking about Coleridge's text was structured around several layers of cartographical representation. On the first level, a 'base map' charted Coleridge's pedestrian movement around the western half of the Lake District between 1 and 9 August 1802. At the second tier (see figure 4), 'analytic' maps drew upon density smoothing techniques - frequently used to visualize geo-specific quantitative data - to map out the place-name references within Coleridge's account of his embodied geographical experiences. The third cartographic layer moved towards subjective, qualitative cartographies through the creation of exploratory 'mood' maps: GIS which mapped out, through detailed textual engagement, Coleridge's emotional responses to named places within the Cumberland landscape.

\section{[Insert figure 4]}

\section{Figure 4: Analytic GIS of Coleridge's 1802 Tour}

The multiple reader-generated GIS produced for the 'Mapping the Lakes' project functioned in several intersecting ways. The foundational GIS, for example, provided a helpful visualization of Coleridge's trajectory during his nine-day walking tour; a cartography, then, which enabled the user to locate the writer's embodied movements in both spatial and temporal contexts. The quantitative mapping of Coleridge's predilection for nomenclature identified the east of Wastwater - a location 
where the slopes of Scafell run down into the vale of Eskdale - as the site at which Coleridge's place-naming was its most prolific. Whilst the production of a 'mood map' suggested that the emotional centre of Coleridge's tour can be located, not coincidentally, at the same precipitous site. Although the three layers of readergenerated mapping facilitated further critical thinking about Coleridge's text, however, all three representational levels reinforced a principal weakness of Moretti's literary geography in that the reader-generated GIS were dislocated, in presentational terms, from the literary texts that had been mapped. This was a problem which was circumnavigated, at the fourth and final mapping tier as textual and cartographical representations of the Lake District landscape were directly linked through the use of Google Earth. By extension, the use of this 'gorgeous-looking interactive digital earth' (Crampton 2010: 27) allowed users to gain a greater understanding of the contoured topography across which Coleridge walked at the beginning of August 1802.

Although 'Mapping the Lakes' demonstrated the critical potentiality offered by the move towards reader-generated digital literary maps, though, it is vital to end this chapter by acknowledging some of that project's critical flaws and omissions: weaknesses and lacunae which ought to be addressed in future digital mappings of Coleridge's walking tour and, more generally, future developments in the interdisciplinary field of critical literary cartography. The layers of GIS and Google Earth maps were produced, for example, by mapping a composite text created through the conflation of two separate sources: the contents of Coleridge's Lake District notebook; and the poet's series of self-aggrandizing letters to Sara Hutchinson. There is a need, then, to produce a striated range of digital cartographies which would allow users to trace the imaginative convergences and discrepancies between the two textual accounts (through the digital presentation of original manuscript material) of 
Coleridge's geographical experience. The renewed emphasis on textuality would, in turn, prompt greater consideration of the material spatiality of Coleridge's pocketbook; and, by extension, reader-generated digital mappings might be placed alongside, or even layered on top of, digitized versions of Coleridge's own authorial cartographies. Authorial and reader-generated mappings, therefore, might be emplaced within a single, dynamically multi-layered cartographical space.

This palimpsestic layering of creative and critical cartographies might be packaged within a desktop format; but, saliently, such digital literary mappings might also be presented through media which can be accessed in-the-field. For instance, applications for GPS-enabled mobile telephones might be developed which would allow users to engage with digitized versions of Coleridge's texts and authorial mappings, as well as existing reader-generated mappings, whilst they are physically moving through the topographies which have been subjected to the imbricated processes of textual and cartographical representation. ${ }^{13}$ Alternatively, authoring environments, such as Mscape, might be used: devices which enable digital media to be triggered according to an individual user's embodied positionality within the landscape (Stenton et al 2007). As well as allowing users to access a digital version of Coleridge's pocketbook whilst they are situated in the valley of Wasdale, for instance, such location-aware mobile technologies would also present opportunities for new user-generated mappings to be placed alongside, or draped over, extant authorial and reader-generated critical maps: processes which would further enrich the cartographic intertextuality of the Cumberland landscape.

\section{Conclusion: Towards a Digitized Critical Literary Cartography}


As part of his fourfold critique of the methodology articulated in the Atlas of the European Novel, Thacker questions what he perceives to be Moretti's positivist understanding of maps and mapping practices. It is a critique which, in turn, points towards the ways in which Harley's theoretical deconstruction of 'cartography's imbrication with power' (Thacker 2005/6: 60) might inform both the analysis of authorial maps and the production of reader-generated mappings in the development of a critical literary cartography. Clearly, emergent digital technologies allow geocritics to present, produce and use literary maps in a series of intersecting ways: from the re-presentation of authorial maps through the digitization of original manuscript material to the use of GIS to produce new cartographies based upon critical readings of the literature of space and place; from the use of hand-held devices to enhance in-the-field literary mapping practices to the creation of virtual spaces in which users might upload their own interpretative maps of key literary texts. In a salient echo of Thacker's critique of Moretti's model of literary geography, however, Lilley argues for 'a more critical use of GIS in humanities research' which draws upon Harley's 'philosophy of cartography' in order 'to think a little more deeply about the processes we are involved in and also the effects (and agency) our own digital maps may have' (Lilley 2011: 30). It is imperative, then, that, in embracing the rich possibilities offered by a suite of digital mapping technologies (including the use of GIS), the critical literary cartographer remains alert to the ways in which all mapping practices are inescapably 'situated, embodied, partial' (Gregory 1994: 140). In other words, there is a need for digitized literary cartography to be underpinned by a critical self-reflexiveness regarding the nature of maps and mapping processes. In a critical review of the spatialization of much literary discourse, the historical geographer, Miles Ogborn argues that: "The "mapping" of this and the "cartographies" of that [ . . 
] promised to reveal new dimensions of spaces and texts but ultimately failed to do any more than indicate that each was "a bit like" the other' (Ogborn 2005/6: 145). Ultimately, then, the use of digital technologies will facilitate both the recartographization of literary mapping practices and will open up dynamic ways of thinking critically about both the interdigitations and disjunctures between textual and cartographical representations of geographical space.

\section{Endnotes:}




\section{References}

Bicknell, P. (1990). The Picturesque Scenery of the Lake District, 1752-1855: A

Bibliographic Study (Winchester: St. Paul's Bibliographies).

Carlson, J. S. (2010). ‘Topographical Measures: Wordsworth’s and Crosthwaite's Lines on the Lake District', Romanticism, 16 (1): 72-93.

Cheshire, P. (2009). 'Coleridge's Notebooks', in F. Burwick (ed.), The Oxford Handbook of Samuel Taylor Coleridge (Oxford: Oxford University Press), pp. 288-306.

Coburn, K. (1957a). 'Introduction', in K. Coburn (ed.) The Notebooks of Samuel Taylor Coleridge: Vol. I (London: Routledge \& Kegan Paul), pp. xvii-xli.

Coburn, K. (1957b). The Notebooks of Samuel Taylor Coleridge: Vol. I, Notes (London: Routledge \& Kegan Paul).

Coburn, K. (1974). The Self Conscious Imagination: A Study of the Coleridge Notebooks (Oxford: Oxford University Press).

Coleridge, S. T. (1802). Notebook 2 (British Library MSS: Add 47497).

Coleridge, S. T. (1957). K. Coburn (ed.), The Notebooks of Samuel Taylor Coleridge, Vol. I (London: Routledge \& Kegan Paul). 
Cooper, D. and Gregory, I. N. (2011). 'Mapping the English Lake District: A Literary GIS', Transactions of the Institute for British Geographers, 36: 89-108.

Cosgrove, D. (1999). 'Introduction: Mapping Meaning', in D. Cosgrove (ed.), Mappings (London: Reaktion), pp. 1-23.

Cosgrove, D. (2008). Geography and Vision: Seeing, Imagining and Representing the World (London: I. B. Tauris).

Crampton, J. W. (2010). Mapping: A Critical Introduction to Cartography and GIS (Chichester: Wiley-Blackwell).

Cuddy-Keane, M. (2002). 'Imaging/Imagining Globalization: Maps and Models', $<$ www.homes.chass.utoronto.ca/ mouddy/mapping.htm $>$

Daniels, S., DeLyser, D., Entrikin, J. N. and Richardson, D. (2011). 'Introduction: Envisioning Landscapes, Making Worlds', in S. Daniels, D. DeLyser, N. J. Entrikin and D. Richardson (eds.), Envisioning Landscapes, Making Worlds: Geography and the Humanities (London: Routledge), pp. xxvi-xxxii.

Genette, G. (1997). J. E. Tewin (trans.), Paratexts: Thresholds of Interpretation (Cambridge: Cambridge University Press).

Gregory, D. (1994). Geographical Imaginations (Oxford: Blackwell). 
Gregory, I. N. and Cooper, D. (2009). 'Thomas Gray, Samuel Taylor Coleridge and Geographical Information Systems: A Literary GIS of Two Lake District Tours', International Journal of Humanities and Arts Computing, 3: 61-84.

Hankinson, A. (1993). Coleridge Walks the Fells: A Lakeland Journey Retraced (London: Fontana).

Harley, J. B. (2001). 'Texts and Contexts in the Interpretation of Early Maps', in P. Laxton (ed.), The New Nature of Maps: Essays in the History of Cartography (Baltimore: The Johns Hopkins University Press), pp. 33-49.

Hewitt, R. (2010). Map of a Nation: A Biography of the Ordnance Survey (London: Granta).

Huddleston, C. R. (1974). 'Introduction', in W. Hutchinson, The History of the County of Cumberland: Volume I (Wakefield: EP Publishing), pp. v-xxii.

Jarvis, R. (1997). Romantic Writing and Pedestrian Travel (Basingstoke: Palgrave).

Kerrigan, J. (1998). 'The Country of the Mind', Times Literary Supplement, 11 September: 34.

Kitchin, R. and Dodge, M. (2007). 'Rethinking Maps', Progress in Human Geography, 31 (3): $331-44$. 
Kitchin, R., Perkins. C. and Dodge, M. (2009). 'Thinking about Maps', in M. Dodge, R. Kitchin and C. Perkins (eds.), Rethinking Maps: New Frontiers in Cartographic Theory (London: Routledge), pp. 1-25.

Lefebure, M. (1974). Cumberland Heritage (London: Arrow).

Lilley, K. D. (2011). 'Digital Cartographies and Medieval Geographies', in S. Daniels, D.

DeLyser, J. N. Entrikin and D. Richardson (eds.), Envisioning Landscapes, Making Worlds:

Geography and the Humanities (London: Routledge), pp. 25-33.

Macfarlane, R. (2003). Mountains of the Mind: A History of a Fascination (London: Granta).

Macfarlane, R. (2007). The Wild Places (London: Granta).

Moretti, F. (1998). Atlas of the European Novel 1800-1900 (London: Verso).

Ogborn, M. (2005/6). 'Mapping Words', New Formations, 57: 145-9.

Perry, S. (2002). 'Introduction', in S. Perry (ed.), Coleridge's Notebooks: A Selection (Oxford: Oxford University Press), pp. vii-xiv.

Richardson, D. (2011). 'Foreword: Converging Worlds: Geography and the Humanities', in S. Daniels, D. DeLyser, J. N. Entrikin and D. Richardson (eds.), Envisioning Landscapes, Making Worlds: Geography and the Humanities (London: Routledge), pp. xix-xxi. 
Richardson, D., Luria, S., Ketchum, J. and Dear, M. (2011). 'Introducing the Geohumanities', in GeoHumanities: Art, in M. Dear, J. Ketchum, S. Luria and D. Richardson (eds.) History, Text at the Edge of Place (London: Routledge), pp. 3-4.

Stenton, S. P., Hull, R., Goddi, P. M., Reid, J. E., Clayton, B. J., Melamed, T. J. and Wee, S. (2007). 'Mediascapes: Context-Aware Multimedia Experiences', IEEE Multimedia, 14: 98105.

Thacker, A. (2005/6). 'The Idea of a Critical Literary Geography', New Formations, 57: 5673.

Westphal, B. (2011). R. T. Tally Jr. (trans.), Geocriticism: Real and Fictional Spaces (New York: Palgrave Macmillan).

Woof, R. (2003). 'Postscript', in S. Morley (ed.), The Unfortunate Tourist of Helvellyn and his Faithful Dog (Grasmere: The Wordsworth Trust), pp. 91-100.

Worthen, J. (2010). The Cambridge Introduction to Samuel Taylor Coleridge (Cambridge: Cambridge University Press). 
1 As Richardson points out in his Foreword, Envisioning Landscapes, Making Worlds, 'is one of two distinctive publications with roots in a seminal Geography and the Humanities Symposium organized by the Association of American Geographers in 2007 at the University of Virginia' (Richardson 2011: xx). The editors of the second collection of essays coin the neologism, 'geohumanities', to refer 'to the rapidly growing zone of creative interaction between geography and the humanities' (Richardson et al 2011: 3).

2 My own terms, authorial and reader-generated mappings, are synonymous with the labels writerly and readerly mappings I have used in an earlier publication (Cooper and Gregory 2011: 91) but which, on reflection, perhaps carry distractedly post-structuralist connotations.

3 'Geocriticism' is the term used by Bertrand Westphal (2011) to define a new 'geocentred' form of literary criticism. Although there are clear divergences between Westphal's geocritical methodology and the more modest aims of the present chapter, there are also analogous interdisciplinary preoccupations.

4 The chronological structure which Coburn imposes means that the reference (1207) given parenthetically denotes Coburn's numbering of an individual notebook entry rather than a conventional page number.

5 The complete spatial narrative of Coleridge's 1802 tour can only be gleaned through a textual braiding of the contents of the pocketbook and the series of letters written to Sara Hutchinson. The descent of Broad Stand, for example, only receives a cursory description in the pocketbook which Coleridge used for on-thespot note-taking; but the account offered in the letter to Sara is more expansively detailed. There is a danger, though, that the endeavour to construct a composite text may lead to a critical marginalization of the cardinal differences between Coleridge's processual notebook entries and his reflective epistolary prose: an insensitivity which problematized the digital cartographies produced as part of the 'Mapping the Lakes' project.

6 As Paul Cheshire points out: 'The first user of the notebooks was Coleridge himself' (Cheshire 2009: 292).

7 Coburn reproduces the corrections and strikethroughs - such as ' original pocketbooks: an editorial decision which facilitates the reader's sense of the processual nature of the poet's spatial and note-taking practices. Please note that Coleridge's idiosyncratic and inconsistent spellings (for example, 'Wastdale') have been retained.

8 I am grateful to the map historian, Paul Hindle, for this information.

9 For Harley, eighteenth-century county maps exemplify the ideological arguments embedded within cartographical representations of space: arguments which are posited through a complex interpenetration of visual signifiers and silences (Harley 2001: 128-34). 
10 The Claude glass was a small visual aid - named after the seventeenth-century French landscape painter, Claude Lorraine - which became integral to Picturesque geovisualization strategies. According to Robert Woof, 'the nature of the Claude glass is a complex matter' as there were two distinct types of Picturesque tool which, by the nineteenth-century, had become confused: the first was 'a dark tinted convex mirror, which involved the artist turning his back on the landscape, and thus seeing the landscape reduced to the convenience of his drawing'; whilst the second 'could be a series of framed pieces of different coloured plain glass, which tinted the scenery to entertain the viewer' (Woof 2003: 91-2).

11 'Paratext' is a term coined by Gérard Genette (1997) to refer to those textual elements - such as titles, forewords, epigraphs and so on - which are situated around and outside the main body of text and which are often introduced by editors, printers or publishers rather than the named author.

12 The interdisciplinary 'Mapping the Lakes' project, which was made possible by an award from the British Academy (SG46004), was based at Lancaster University: www.lancaster.ac.uk/mappingthelakes. For further technological and theoretical reflections on this project see Gregory and Cooper (2009) and Cooper and Gregory (2011).

13 Faber \& Faber have begun to explore the ways in which manuscript materials might be presented via hand-held devices through their development of an interactive iPad application for T. S. Eliot's great Modernist poem, The Waste Land. Similarly, Penguin Books have developed an 'amplified edition' of Jack Kerouac's Beat novel, On the Road, for the iPad: an application which presents digital literary maps which can be accessed by users whilst situated at geographical locations represented in Kerouac's fictional text. 